\title{
電解質を添加した無水有機溶媒中における 鉄の腐食と抑制
}

\author{
荒 牧 國 次* \\ $*$ 慶応義塾大学理工学部名誉教授 \\ Corrosion of Iron in Anhydrous Organic Solvents
Containing Electrolytes and Its Inhibition \\ Kunitsugu Aramaki* \\ * Professor Emeritus, Keio University
}

\begin{abstract}
Our recent studies on corrosion of iron in anhydrous organic solvents containing electrolytes are reviewed. Iron corrodes in an anhydrous methanol containing $0.1 \mathrm{M} \mathrm{LiClO}_{4}$ forming a precipitate of ferrous methoxide $\mathrm{Fe}\left(\mathrm{OCH}_{3}\right)_{2}$ on the iron surface. Similar electrochemical corrosion of iron to that in an aqueous solution occurs in anhydrous acetonitrile and dimethylformamide solutions of carboxylic acids. The anodic process of iron corrosion in the anhydrous methanol solution is stimulated by adding complexing agents to form soluble complexes with $\mathrm{Fe}^{2+}$ at the surface. Accelerated corrosion of iron occurs in anhydrous methanol and acetonitrile solutions containing $\mathrm{FeCl}_{3}$ and is suppressed by the addition of adsorption-type corrosion inhibitors effectively.
\end{abstract}

Key words: iron corrosion, anhydrous organic solvents, polarization, impedance, XPS, carboxylic acids, complexing agents, $\mathrm{FeCl}_{3}$, adsorption-type inhibitors

\section{1.はじめに}

常温付近での金属の腐食現象は水の存在なしには語れ ない。しかし，水のほとんご存在しない非水溶媒中でも 腐食は起こる。水以外の無機溶媒に一般的なものはない ので, 非水溶媒は有機溶媒と考えてよい。含水量の低い 溶媒中の腐食現象は水溶液中のような水が関係した腐食 と比べて極端に違う現象ととられることがあるが，よく 考えてみると特別な現象ではない。たとえば， $\mathrm{Al}$ が沸 騰した水のない酷酸中で激しい腐食を起こすのは，Al 表面の不働態皮膜が存在しない状態では普通の現象であ る。

電解質を含む無水有機溶媒中で起こる腐食反応の大部 分は電気化学的な反応である。ここ十年あまり，筆者の 研究室で比較的含水量の低い（500 ppm 以下）有機溶 媒中での電気化学的腐食について研究してきたので, そ の成果をまとめてみたいと思う。

\footnotetext{
* 干223-8522 横浜市港北区日吉 3-14-1（3-14-1, Hiyoshi, Kohoku-ku, Yokohama, 223-8522 Japan)
}

\section{2. 有機溶媒中の金属の腐食}

まず，一般的な有機溶媒中における金属腐食について 簡単に述べよう。なお, 詳しく知りたい方は Heitz の 著書 $^{1)}$, 筆者の便覧 ${ }^{2)}$ や解説 ${ }^{3)}$, その他の解説 ${ }^{4)}$ や総合 論文 ${ }^{5)}$ を参照されたい。

有機溶媒は溶媒分子に電気的な片寄りのない非極性分 子と片寄りのある極性分子に大別される。前者は双極子 モーメント $\mu=0$ で, 比誘電率 $\varepsilon$ が小さく, 後者は $\mu>$ 0 で, $\varepsilon$ が大きい。極性溶媒は静電気的に溶媒和しやす いので, イオンを溶解して電解質溶液になりやすく, そ の中で電気化学的な腐食が起こりやすい。表 1 に代表的 な溶媒をあげた。もう一つの分類に, 溶媒が $\mathrm{H}^{+}$を放出 するプロトン性 (protic) 溶媒と放出しない非プロトン 性（aprotic）溶媒がある。たとえば, 酢酸やメタノー ルは

$$
\begin{aligned}
& \mathrm{CH}_{3} \mathrm{COOH} \longrightarrow \mathrm{H}^{+}+\mathrm{CH}_{3} \mathrm{COO}^{-} \\
& \mathrm{CH}_{3} \mathrm{OH} \longrightarrow \mathrm{H}^{+}+\mathrm{CH}_{3} \mathrm{O}^{-}
\end{aligned}
$$

のように解離して $\mathrm{H}^{+}$を放出する。プロトン性溶媒はそ れ自身でイオンを生成するので, 純粋な溶媒であっても 
表 1 主な溶媒の性質

\begin{tabular}{|c|c|c|c|c|c|c|c|}
\hline 溶 & 媒 & 分 & 類 & $\begin{array}{c}\text { 双極子モ } \\
\text { 一寺 } \\
\mu \\
\text { (debye) }\end{array}$ & $\begin{array}{c}\text { 比誘電率 } \\
\varepsilon\end{array}$ & $\begin{array}{c}\text { ドナー数 } \\
D_{\mathrm{N}}\end{array}$ & $\begin{array}{l}\text { アクセプ } \\
\text { ター数 } A_{\mathrm{N}}\end{array}$ \\
\hline ヘキサン & $\mathrm{C}_{6} \mathrm{H}_{14}$ & 非極性 & $a$ & 0 & 1.89 & - & 0.0 \\
\hline ベンゼン & $\mathrm{C}_{6} \mathrm{H}_{6}$ & $"$ & a & 0 & 2. 28 & 0.1 & 8.2 \\
\hline $\begin{array}{l}\text { 四塩化炭素 } \\
\text { ジエチルエー }\end{array}$ & $\begin{array}{c}\mathrm{CCl}_{4} \\
\text { 一テル }\end{array}$ & $"$ & $\mathrm{a}$ & 0 & 2.24 & - & 8. 6 \\
\hline & $\left(\mathrm{C}_{2} \mathrm{H}_{5}\right)_{2} 0$ & 性 & $a$ & 1.06 & 4. 19 & 19.2 & 3.9 \\
\hline ピリジン & $\mathrm{C}_{5} \mathrm{H}_{5} \mathrm{~N}$ & $"$ & a & 2.15 & 12.3 & 33.1 & 14.2 \\
\hline 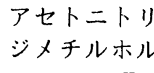 & $\begin{array}{l}\text { リ } \mathrm{CH}_{3} \mathrm{CN} \\
\text { ルムアミド }\end{array}$ & $"$ & a & 3.89 & 37.5 & 14.1 & 18.9 \\
\hline & $\mathrm{ON}\left(\mathrm{CH}_{3}\right)_{2}$ & $"$ & a & 3.82 & 36.7 & 26.6 & 16.6 \\
\hline メタノール & $\mathrm{CH}_{3} \mathrm{OH}$ & $"$ & $\mathrm{p}$ & 1.69 & 32.6 & 23.5 & 41. 3 \\
\hline エタノール & $\mathrm{C}_{2} \mathrm{H}_{5} \mathrm{OH}$ & $"$ & $\mathrm{p}$ & 1. 44 & 24.3 & - & 37.1 \\
\hline ギ＼cjkstart酸 & $\mathrm{HCOOH}$ & $"$ & $\mathrm{p}$ & 1. 41 & 58.5 & $\sim 17$ & - \\
\hline 酢＼cjkstart酸 & $\mathrm{CH}_{3} \mathrm{COOH}$ & $"$ & $\mathrm{p}$ & 1.70 & 6.15 & - & 52.9 \\
\hline ホルムアミト & ド $\mathrm{HCONH}_{2}$ & $"$ & $\mathrm{p}$ & 3.71 & 109 & 24.7 & 39.8 \\
\hline 水 & $\mathrm{H}_{2} \mathrm{O}$ & $"$ & $\mathrm{p}$ & 1.94 & 78.5 & 18.0 & 54.8 \\
\hline
\end{tabular}

生成によって行われると言われている11)。 これらの皮膜が溶液中で安定であれば, 腐 食反応は著しく抑制される。

非水溶液中における金属腐食の大部分は 電気化学反応によって進行する。十分な電 気伝導性を持つ電解質溶液中では, 酸の混 入は

$$
2 \mathrm{H}^{+}+2 \mathrm{e}^{-} \longrightarrow \mathrm{H}_{2}
$$

によってカソード反応を促進する。 $\mathrm{O}_{2}$, $\mathrm{Fe}^{3+}, \mathrm{Cu}^{2+}$ のような酸化剂によっても力 ソード反応が促進される。一方，アノード 反応は金属 $\mathrm{M}$ の溶解反応

$$
\mathrm{M} \longrightarrow \mathrm{M}^{2+}+\mathrm{ze}^{-}
$$

で，金属イオンが溶液に可溶であれば，腐 食は進行する。これらの電気化学反応は水 溶液中の反応と同じように考えればよい。

もう一つの非水溶液中における金属の腐

電解質となって電気化学的腐食を起こす可能性がある。 溶媒の性質を示す数值にドナー数 $D_{\mathrm{N}}$ とアクセプター 数 $A_{\mathrm{N}}$ がある。前者は溶媒分子の電子供与性, 後者は電 子受容性を示す数值である。たとえば，ピリジンは

$$
\mathrm{C}_{5} \mathrm{H}_{5} \mathrm{~N}:+\mathrm{H}^{+} \longrightarrow \mathrm{C}_{5} \mathrm{H}_{5} \mathrm{~N}: \mathrm{H}^{+}
$$

のように電子を供与しやすいので $D_{\mathrm{N}}$ は大きく, 酢酸は

$$
\mathrm{CH}_{3} \mathrm{COOH}+\mathrm{X}: \longrightarrow \mathrm{CH}_{3} \mathrm{COOH}: \mathrm{X}
$$

のように電子供与体 $\mathrm{X}:$ から電子を受容しやすいので $A_{\mathrm{N}}$ が大きい。これらは溶媒と溶質が化学結合するよう な化学的な性質を示すもので, 溶媒が錯体を作ったり, 金属表面に化学吸着する場合に重要になることがある。

有機溶媒中の金属腐食に大きく影響する因子は溶質で ある。酸, 塩基, 塩類などの電解質の混入は溶媒の電気 伝導性を増すので電気化学的腐食を促進する。一般に, $10^{-7} \mathrm{Scm}^{-1}$ 以下の比導電率であれば，腐食は問題にな らないと言われている ${ }^{6)}$ 。しかし，極性溶媒に微量の電 解質が混入すると, イオン解離して電気伝導性が増大す る ${ }^{7)}$ 。さらに, $\mathrm{H}^{+}$や $\mathrm{O}_{2}$ などの酸化剤の存在は電気化 学的腐食反応を促進する。有機溶媒中への $\mathrm{O}_{2}$ の溶解度 は水中よりも大きいので注意が必要である。また，水の 混入が溶媒の極性を強める方向に作用することもある。

あまり多くのデー夕はないが，一般に有機溶媒中にお ける金属の標準電極電位 $E^{\circ}$ の相対的な関係は水溶液中 のものがほぼ保たれている8),9)。たとえば， $E^{\circ}{ }_{\mathrm{Cu}}>E^{\circ}{ }_{\mathrm{Ni}}$ $>E^{\mathrm{o}}{ }_{\mathrm{Fe}}>E^{\mathrm{o}}{ }_{\mathrm{Zn}}$ である ${ }^{10)}$ 。金属表面の性質として重要な のは不㗢態皮膜の生成である。 $\mathrm{Al}, \mathrm{Ti}$, ステンレス鋼の 上うな金属では水の存在が不働態皮膜の生成に必要であ る。非水溶液中では，金属の不働態化は（a）大気中で 生成した酸化皮膜，（b）塩の沈殿皮膜，（c）溶媒の化 学吸着, (d) 酸化物およびオキシ水酸化物沈殿皮膜の
食反応として化学的な腐食反応がある。有機合成に使わ れるグリニヤール試薬は $\mathrm{Mg}$ と臭化アルキル $\mathrm{RBr}$ が無 水ジエチルエーテル中で反応して作られ， $\mathrm{Mg}$ はエーテ ル中に溶解する ${ }^{12)}$ 。

$$
\mathrm{Mg}+\mathrm{RBr} \longrightarrow \mathrm{RMgBr}
$$

この反応は電解質の全くないエーテル中で起こるので, 化学的反応と考えられる。

沸騰無水四塩化炭素中で $\mathrm{Al}$ や $\mathrm{Ti}$ が少しの誘導期間 の後に激しい腐食によって溶解する ${ }^{13)}, 14$ 。

$$
2 \mathrm{Al}+6 \mathrm{CCl}_{4} \longrightarrow 2 \mathrm{AlCl}_{3}+3 \mathrm{C}_{2} \mathrm{Cl}_{6}
$$

この反応は $\mathrm{CCl}_{4}$ から反応性に富んだ遊離基が生成し て, ラジカル反応によって進行すると言われているが, 電気化学反応と考える異論もある ${ }^{15)}$ 。電気陰性度の低 い金属之高い $\mathrm{Br}$ や $\mathrm{Cl}$ の化合物の反応であるから，イ オン的な反応が含まれるのは当然であろう。

以下に筆者の研究室で行った研究について述べよう。

\section{3. 電解質無水メタノール中の $\mathrm{Fe}$ の腐食 ${ }^{16), 18)}$}

実験に用いた金属はすべて $99.99 \% \mathrm{Fe}$ である。溶媒

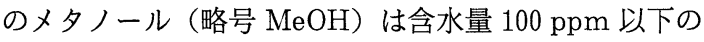
液体クロマトグラフ用のものをそのまま用いた。電解質 は特に断りがない限り $0.1 \mathrm{M}\left(\mathrm{molcm}^{-3}\right) \mathrm{LiClO}_{4}$ で ある。十分に水の混入を避けるように注意しても, 実際 に腐食測定を行った後の含水量は 100〜 500 ppm になっ ていた。含水量増加の主な原因は大気からの混入とガラ 不容器に吸着した水分と思われ，溶液の調製から測定ま でを乾燥アルゴン雾囲気のグローブボックス（後述）中 で行ってはじめて $100 \mathrm{ppm}$ 以下の含水量にすることが できた。電気化学測定に用いる参照電極は同じ溶媒を用 いた $\mathrm{Ag} / \mathrm{AgCl}$ 電極あるいは $\mathrm{Ag} / \mathrm{Ag}^{+}$電極を用いた。 


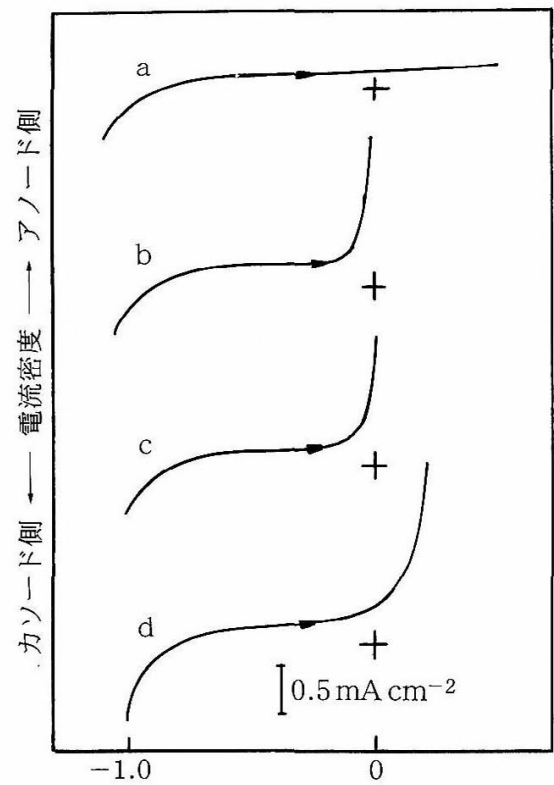

電 位 / V vs. $\mathrm{Ag} / \mathrm{AgCl}(\mathrm{MeOH})$

図 1 種々の電解質を加えた $\mathrm{MeOH}$ 中における大気 中で調製した $\mathrm{Fe}$ 電極の動電位アノード分極曲 線16)

(a) $0.1 \mathrm{M} \mathrm{LiClO}_{4}$, (b) $0.1 \mathrm{M} \mathrm{LiCl,} \mathrm{(c)}$ $0.1 \mathrm{M} \mathrm{LiBr}$, (d) $0.1 \mathrm{M} \mathrm{NaI}$

水溶液参炤電極は水の混入と液間電位差が大きいので用 いない方がよい。

$\mathrm{Fe}$ 電極表面の調製は大気中でエメリ一紙（3000 番ま で）とアルミナ粉 $(1 \mu \mathrm{m})$ で研磨した後, $\mathrm{MeOH}$ 中で 超音波洗浄し，大気中で乾燥した。この電極のアノード 分極曲線をそれぞれ $0.1 \mathrm{M} \mathrm{LiClO}_{4}, 0.1 \mathrm{M} \mathrm{LiCl}, 0.1$ $\mathrm{M} \mathrm{LiBr}, 0.1 \mathrm{M} \mathrm{NaI}$ を含む $\mathrm{MeOH}$ 中で測定したとこ ろ，図10ように電流の急激な立ち上がりがみられ，そ の電位は $\mathrm{LiCl}<\mathrm{LiBr}<\mathrm{NaI} \ll \mathrm{LiClO}_{4}$ の順であった。 この順位は水溶液中において $\mathrm{Fe}$ 表面の不働態皮膜が侵 食性アニオンによって破壊されるときの電位の順位と一 致し, $\mathrm{Fe}$ 表面に不働態皮膜の存在が示唆された ${ }^{17)}$ 。事 実，図 2 に示すように, $0.1 \mathrm{M} \mathrm{LiClO}_{4}$ 中に浸漬した $\mathrm{Fe}$ 表面にはほとんどピットの生成が見られないのに，0.1 $\mathrm{M} \mathrm{LiCl}$ 中では表面にピットが生成した。500 ppm 以下 の含水量の $\mathrm{MeOH}$ 中では $\mathrm{Fe}$ 表面に不㗢態皮膜は生成 しないと報告されているので18), 大気中で $\mathrm{Fe}$ 表面を調 製したときに生成した酸化物皮膜が $\mathrm{MeOH}$ 中で不働態 皮膜として作用したと結論した ${ }^{16)}$ 。

以上のように, 無水 $\mathrm{MeOH}$ 中における $\mathrm{Fe}$ の腐食挙 動を調べるには不活性気体中で $\mathrm{Fe}$ 表面の研磨, 洗浄を する必要があり,空気と水の混入の少ないアルゴン $\left(\mathrm{O}_{2}\right.$ <0. $01 \mathrm{ppm}, \mathrm{H}_{2} \mathrm{O}<5 \mathrm{ppm}$ ) を満たしたグローブボッ

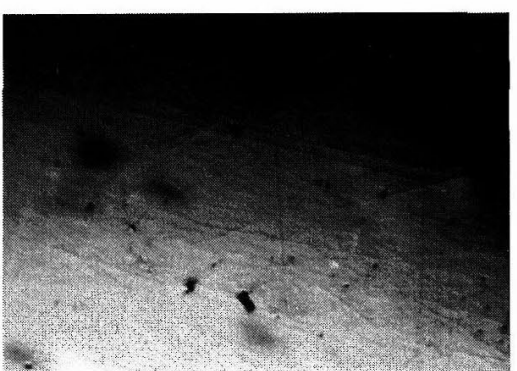

(a)

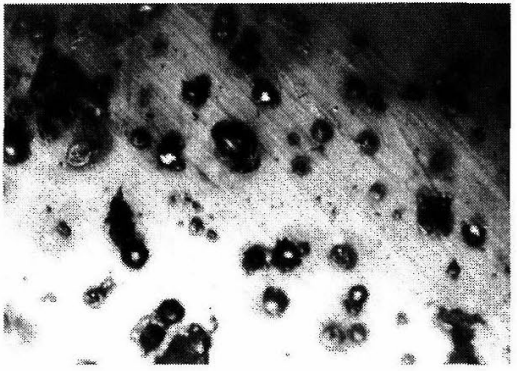

(b)

図2 大気中で調製した後, (a) $0.1 \mathrm{M} \mathrm{LiClO}_{4}$ および (b) $0.1 \mathrm{M} \mathrm{LiCl}$ に $5 \mathrm{~h}$ 浸漬した $\mathrm{Fe}$ 電極表面の 顕微鏡写真 ${ }^{16\rangle}$

クス中で表面調製し，さらに電気化学測定もひき続きそ の中で行うことで, 水の混入と大気中で生成する酸化皮 膜の影響を除くここができた。図 3 はこの実験に用いた グローブボックスと $\mathrm{Fe}$ 電極表面のアルミナ研磨および 電気化学測定時のセルの様子を示している。

$0.1 \mathrm{M} \mathrm{LiClO}_{4}$ を含む無水 $\mathrm{MeOH}$ 中の $\mathrm{Fe}$ の腐食挙動 を調ベるために，インピーダンス測定により電荷移動抵 抗の逆数であるファラデーコンダクタンス $K_{\mathrm{f}}$ を求め た。腐食電位における $K_{\mathrm{f}}$ は腐食速度に対応するので, $K_{1}$ の時間変化を測定したところ，図 4 のように $K_{\mathrm{f}}$ は 時間と共に減少した。この結果から，無水 $\mathrm{MeOII}$ 中で $\mathrm{Fe}$ は腐食し，生成した腐食生成物の沈殿が表面を覆う ために腐食速度が減少すると考えた。 $\mathrm{Fe}$ は $\mathrm{MeOH}$ と 反応し

$$
\mathrm{Fe}+2 \mathrm{CH}_{3} \mathrm{OH} \longrightarrow \mathrm{Fe}\left(\mathrm{OCH}_{3}\right)_{2}+\mathrm{H}_{2}
$$

生成した鉄メトキシド $\mathrm{Fe}\left(\mathrm{OCH}_{3}\right)_{2}$ が $\mathrm{MeOH}$ に不溶で あるために, $\mathrm{Fe}$ 表面に沈殿皮膜を作る。反応後の $\mathrm{Fe}$ 表面の X 線光電子分光法 (XPS) に上る分析で，表面 に鉄メトキシドの沈殿が認められた ${ }^{16), 193} 。 \mathrm{MeOH}$ がプ ロトン性溶媒であることから考えれば，(2)式により生 成した $\mathrm{H}^{+}$のカソード還元反応 (5) 式と $\mathrm{Fe}$ のアノード 溶解反応 (6) 式の電気化学反忘によってこの反応は起こ り，生成した $\mathrm{Fe}^{2+}$ と $\mathrm{CH}_{3} \mathrm{O}^{-}$が反応して鉄メトキシド の沈殿を表面で作ると考えるのが妥当である。 


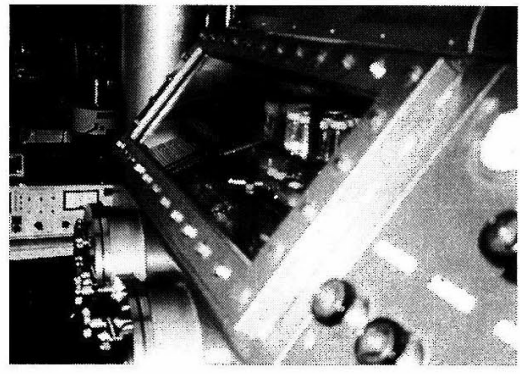

(a)

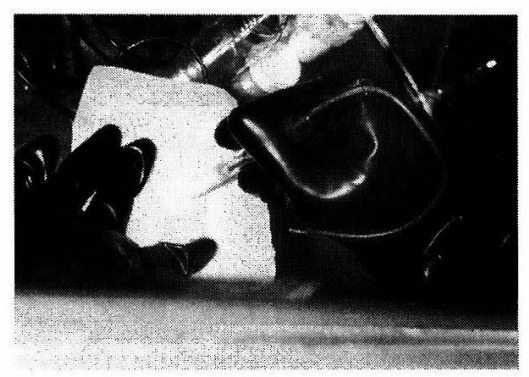

(b)

図 3 グローブボックス (a)とその中における Fe 電極表面のアルミナ研 磨 $(b)^{3)}$ および電気化学測定用セル (c)

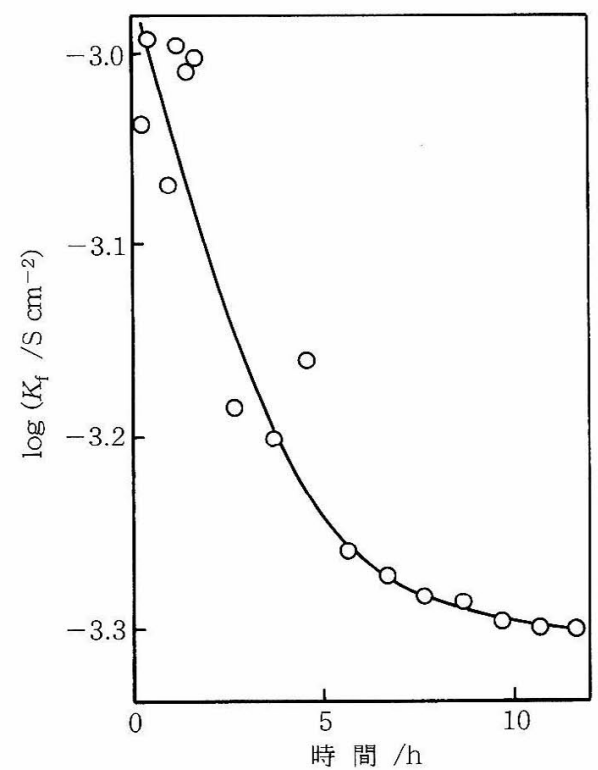

図 $40.1 \mathrm{M} \mathrm{LiClO}_{4}$ 添加無水 $\mathrm{MeOH}$ 中における $\mathrm{Fe}$ 電極 のファラデーコンダクタンス $K_{\mathrm{f}}$ 亡時間の関係 ${ }^{16)}$

\section{4. プロトン酸を含む無水有機溶媒中の $\mathrm{Fe}$ 腐食 ${ }^{23), 24)}$}

無水 $\mathrm{MeOH}$ 中にギ酸 $\mathrm{HCOOH}$ のようなプロトン酸 を添加すると反応し，

$$
\mathrm{HCOOH}+\mathrm{CH}_{3} \mathrm{OH} \longrightarrow \mathrm{HCOOCH}_{3}+\mathrm{H}_{2} \mathrm{O} \text { (10) }
$$

$\mathrm{H}_{2} \mathrm{O}$ を生成するので腐食系は複雑になる。この反応
は可逆であるので含水量が多い場合

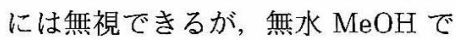
あると配慮が必要となる。図 5 は $0.1 \mathrm{M} \mathrm{NaClO}_{4}$ と $0.5 \mathrm{M} \mathrm{HCOOH}$ を含む無水 $\mathrm{MeOH}$ 中の $\mathrm{HCOOH}$ 濃度 $c$ と $\mathrm{Fe}$ 電極の $K_{\mathrm{f}}$ の時間変化 を示す ${ }^{20)}$ 。 $\log c$ は時間と共に直線 的に減少し, $\mathrm{HCOOH}$ が一次反応 で反応していることを示した。それ に応じて Fe の腐食速度に対応する $K_{\mathrm{f}}$ も減少するが，生成した $\mathrm{H}_{2} \mathrm{O}$ や $\mathrm{HCOOCH}_{3}$ の影響もあった。 $\mathrm{MeOH}$ に $\mathrm{H}_{2} \mathrm{SO}_{4}$ のような強酸を 加える実験が行われるが，無水であ ると,

$$
\begin{aligned}
& \mathrm{H}_{2} \mathrm{SO}_{4}+\mathrm{CH}_{3} \mathrm{OH} \\
& \longrightarrow \mathrm{CH}_{3} \mathrm{OSO}_{3} \mathrm{H}+\mathrm{H}_{2} \mathrm{O}
\end{aligned}
$$

のような反応が起こりやすいので注 意が必要である21)。

無水プロトン性浴媒はプロトン酸 と反応する可能性があるので，非プ ロトン性溶媒のアセトニトリル（略 号 $\mathrm{AN}$ ) とジメチルホルムアミド (DMF) を用い, 支 持電解質 $0.1 \mathrm{M} \mathrm{LiClO}_{4}$ とカルボン酸 $\mathrm{RCOOH}$ (酢酸 $\mathrm{R}: \mathrm{CH}_{3}$, クロロ酢酸 $\mathrm{R}: \mathrm{CH}_{2} \mathrm{Cl}$, 汸ロロ酢酸 $\mathrm{R}$ : $\left.\mathrm{CHCl}_{2}\right)$ を含む溶液中における $\mathrm{Fe}$ 腐食を分極測定に よって検討した。また，比較のために水溶液中でも同様

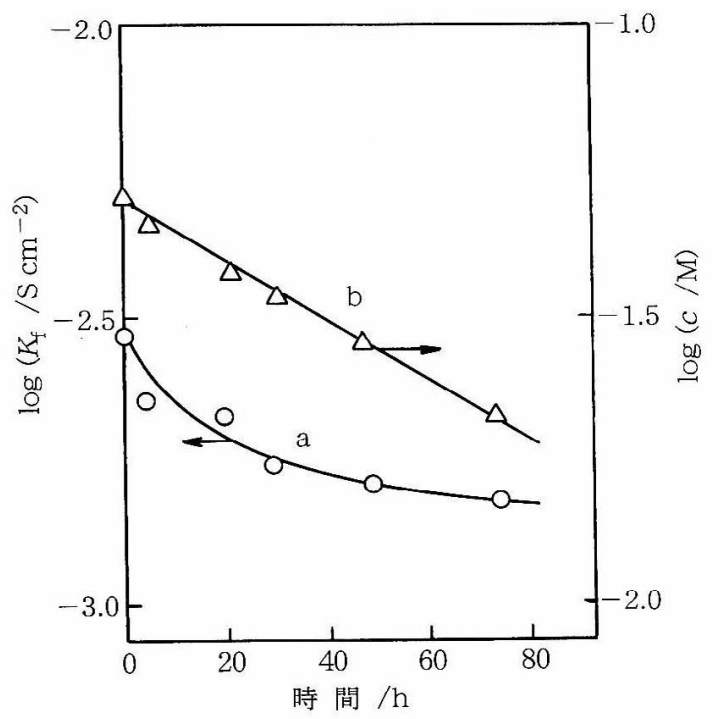

図 $50.1 \mathrm{M} \mathrm{NaClO}_{4}$ と $0.5 \mathrm{M} \mathrm{HCOOH}$ を含む無水 $\mathrm{MeOH}$ 中における (a) $\mathrm{Fe}$ 電極の $K_{\mathrm{f}}$ と（b) $\mathrm{HCOOH}$ 濃度 $c$ の時間变化20) 


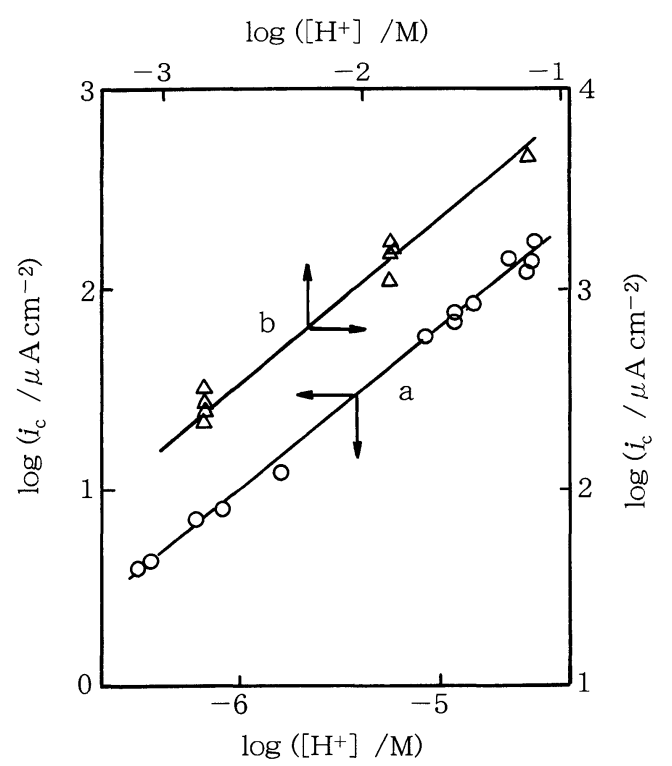

図6 $0.1 \mathrm{M} \mathrm{LiClO}_{4}$ とカルボン酸を含む（a）無水 $\mathrm{A}$ $\mathrm{N}$ および（b）水中における $\mathrm{Fe}$ 腐食のカソード 電流密度 $i_{\mathrm{c}}$ と $\left[\mathrm{H}^{+}\right]$の関係 ${ }^{23)}$

(a) の $i_{\mathrm{c}}$ は $-0.7 \mathrm{~V}$ vs. $\mathrm{Ag} / \mathrm{Ag}^{+}(\mathrm{AN})$, (b)

の $i_{\mathrm{c}}$ は-0.7 V vs. Ag/AgClにおける值

の実験を行った。

これらの非水溶液には 100 数 $100 \mathrm{ppm}$ の水が混入

しており, 溶液中の $\mathrm{H}^{+}$はカルボン酸の解離によるもの

$$
\mathrm{RCOOH} \longrightarrow \mathrm{RCOO}^{-}+\mathrm{H}^{+}
$$

以外に，混入した水により解離した $\mathrm{H}_{3} \mathrm{O}^{+}$が含まれて いる。

$$
\mathrm{RCOOH}+\mathrm{H}_{2} \mathrm{O} \longrightarrow \mathrm{RCOO}^{-}+\mathrm{H}_{3} \mathrm{O}^{+}
$$

$\mathrm{H}^{+}$の反応はカソード反応であるので, カソード分極 曲線のターフェル領域の一つの電位における電流密度 （カソード電流密度 $i_{\mathrm{c}}$ ) を求め, (12)，(13)式による $\mathrm{H}^{+}$ 濃度 $\left[\mathrm{H}^{+}\right]$を解離定数 ${ }^{22)}$ から求め, AN と水中におけ る $\log i_{\mathrm{c}}$ と $\log \left[\mathrm{H}^{+}\right]$の関係を示したものが図 6 であ る。いずれの溶媒中でも直線関係が得られ, $\left[\mathrm{H}^{+}\right]$が高 いほどカソード反応は促進された。水中に比べて AN 中では $\mathrm{RCOOH}$ の解離が少ないので腐食速度は低いが, 直線の勾配がほぼ等しいことは $\mathrm{Fe}$ 表面で同じような力 ソード反応が起こることを示唆している23)。

一方, カルボン酸と $0.1 \mathrm{M} \mathrm{LiClO}_{4}$ を含む $\mathrm{DMF}$ 中で の $\mathrm{Fe}$ 表面におけるカソード反応は(12)式の解離よりも (13) 式により生じた $\mathrm{H}_{3} \mathrm{O}^{+}$と密接な関係があった。こ れは DMF のドナー数 $D_{\mathrm{N}}$ が大きいために, DMF と溶 媒和した $\mathrm{H}^{+} よ り も ~ \mathrm{H}_{3} \mathrm{O}^{+}$の方がカソード反応しやす く, $\left[\mathrm{H}_{3} \mathrm{O}^{+}\right]$が $i_{\mathrm{c}}$ に関連したものと考えた ${ }^{24)} 。$

$1 \mathrm{M} \mathrm{CH} \mathrm{CHCOH}_{2}$ を含む電解質 $\mathrm{DMF}$ 中における $\mathrm{Fe}$ のアノード反応はハロゲン化物イオン $\mathrm{X}^{-}\left(\mathrm{Cl}^{-}, \mathrm{Br}^{-}\right.$,
表 2 錯化剂の酸解離定数 $\mathrm{p} K_{\mathrm{a}}$ と $\mathrm{Fe}^{2+}$ 錯体の安定度

\begin{tabular}{|c|c|c|c|}
\hline 錯化剂 & (略号) & $\mathrm{p} K_{a}$ & $\mathrm{p} K_{\mathrm{st}}$ \\
\hline $\mathrm{NH}_{2} \mathrm{CH}_{2} \mathrm{CH}_{2} \mathrm{NH}_{2}$ & (en) & 14.1 & 9.72 \\
\hline & (dpy) & 9.3 & 17.2 \\
\hline & (phen) & 9.6 & 21.0 \\
\hline $\mathrm{CH}_{3} \mathrm{COCH}_{2} \mathrm{COCH}_{3}$ & (Hacac) & 13.1 & 8. 67 \\
\hline & $\left(\mathrm{H}_{2} \mathrm{cat}\right)$ & 13.3 & 13.5 \\
\hline $\mathrm{HSCH}_{2} \mathrm{CH}(\mathrm{SH}) \mathrm{CH}_{2} \mathrm{OH}$ & $\left(\mathrm{H}_{2} \mathrm{dmp}\right)$ & 12.7 & 28 \\
\hline
\end{tabular}
定数 $\mathrm{p} K_{\mathrm{st}}$

$\mathrm{I}^{-}$）の添加によって促進された。水溶液や $\mathrm{MeOH}$ 溶液 中における $\mathrm{Fe}$ のアノード反応においては, $\mathrm{Cl}^{-}$が促進 することはあっても, $\mathrm{Br}^{-} や \mathrm{I}^{-}$は抑制するのが普通で ある。一般に, 酸性溶液中にハロゲンイオン $\mathrm{X}^{-}$が存在 する場合, $\mathrm{Fe}$ のアノード反応は $\mathrm{X}-$ の吸着過程を含む 触媒反応が起こる25)。

$$
\begin{aligned}
& \mathrm{Fe}+\mathrm{X}^{-} \rightleftarrows\left(\mathrm{FeX}^{-}\right)_{\mathrm{s}} \\
& (\mathrm{FeX})_{\mathrm{s}} \longrightarrow(\mathrm{FeX})_{\mathrm{s}}+\mathrm{e}^{-} \\
& (\mathrm{FeX})_{\mathrm{s}} \longrightarrow(\mathrm{FeX})^{+}+\mathrm{e}^{-} \\
& (\mathrm{FeX})^{+} \rightleftarrows \mathrm{Fe}^{2+}+\mathrm{X}^{-} \\
& (\mathrm{s} \text { は表面物質を示す。 })
\end{aligned}
$$

水溶液や $\mathrm{MeOH}$ 溶液中では(14) 式の吸着した $\mathrm{Br}^{-}$, $\mathrm{I}^{-}$や(15)式の表面錯体が安定であるために, 律速段階 である(16)式が進行しにくいので全体の反応は抑制され る。しかし, DMF 中では DMF の $D_{\mathrm{N}}$ が大きいために $(\mathrm{FeX})^{+}$と DMF との溶媒和が容易であり，その結果 (16)式の速度が大きくアノード反応は促進されたと考え ている24)。

\section{5. 錯化剂を含む無水 $\mathrm{MeOH}$ 中の $\mathrm{Fe}$ 腐食 ${ }^{23), 26), 27)) ~}$}

電解質無水 $\mathrm{MeOH}$ 中においては鉄メトキシドの沈殿 皮膜の生成によって $\mathrm{Fe}$ の腐食反応は時間と共に遅くな る。沈殿皮膜を溶解して反応を促進するために, $\mathrm{Fe}^{2+}$ と反応して錯体を作る錯化剂（表 2 参照）を $0.1 \mathrm{M} \mathrm{Li}$ $\mathrm{ClO}_{4}$ 無水 $\mathrm{MeOH}$ 溶液に添加して, $\mathrm{Fe}$ の分極曲線を測 定した。最初の 3 錯化剂 en, bpy, phen（L で表す。） は $\mathrm{Fe}^{2+}$ と反応する。

$$
\mathrm{Fe}^{2+}+3 \mathrm{~L} \longrightarrow\left[\mathrm{FeL}_{3}\right]^{2+}
$$

生成した錯体が $\mathrm{MeOH}$ に可溶であれば, $\mathrm{Fe}$ 腐食は 促進されるはずである。表 2 の錯体の安定度定数 $\mathrm{p} K_{\text {st }}$ は水溶液の值であるが, $\mathrm{MeOH}$ 中でもこの值が大きい ものほど錯体を作りやすいと考えられる。図 7 に $1 \times$ $10^{-4} \mathrm{M}$ の錯化剂を添加したときの $\mathrm{Fe}$ の分極曲線を示 


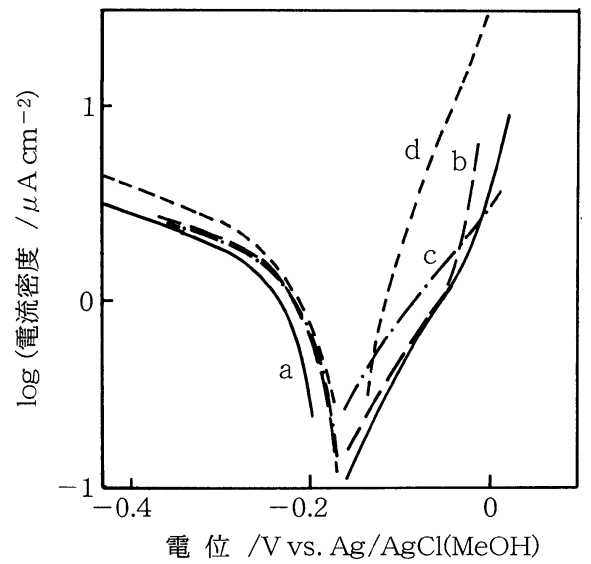

図 $70.1 \mathrm{M} \mathrm{LiClO}_{4}$ と $1 \times 10^{-4} \mathrm{M}$ の錯化剂を含む無水 $\mathrm{MeOH}$ 中における $\mathrm{Fe}$ 電極の分極曲線-1 ${ }^{26)}$

（a）錯化剂無添加，（b）en,（c）bpy,（d） phen 添加

す。カソード反応は $\mathrm{MeOH}$ の解離による $\mathrm{H}^{+}$の還元反 応(5)式であり，アノード反応は(6)式による $\mathrm{Fe}$ の溶解 反応に続く $\mathrm{Fe}^{2+}$ 錯体の生成反応 (18) 式によって $\mathrm{MeOH}$ に溶解する。このため, カソード分極曲線は錯化剂無添 加時とほぼ同じであるが, アノード分極曲線では錯体の $\mathrm{p} K_{\mathrm{st}}$ が大きいものほよ゙ $\mathrm{Fe}^{2+}$ とよく反応するのでア ノード反応は促進され, en $<$ bpy $<$ phen の順に電流密 度は増加した ${ }^{26)}$ 。

その他の錯化剤Hacac, $\mathrm{H}_{2}$ cat, $\mathrm{H}_{2} \mathrm{dmp}$ はいずれも 解離して $\mathrm{H}^{+}$を放出する。たとえば,

$$
\mathrm{Hacac} \longrightarrow \mathrm{H}^{+}+\mathrm{acac}^{-}
$$

表 2 に示す $\mathrm{MeOH}$ 中での酸の解離定数 $\mathrm{p} K_{\mathrm{a}}$ から求 めた $\mathrm{H}^{+}$濃度は $\mathrm{MeOH}$ の解離による $\mathrm{H}^{+}$濃度と同程度 で, カソード反応への寄与は小さかった。そのため, 図 8 に示すように, カソード分極曲線はこれらの錯化剤の 添加の影響をほとんど受けなかった。一方，アノード分 極曲線は影響され，アノード反応はHacac $<\mathrm{H}_{2} \mathrm{dmp}$ の 順に促進され, $\mathrm{H}_{2}$ catによって抑制された。前二者は

$$
\begin{aligned}
& \mathrm{Fe}^{2+}+2 \mathrm{acac}^{-} \longrightarrow\left[\mathrm{Fe}(\mathrm{acac})_{2}\right] \\
& 2 \mathrm{Fe}^{2+}+3 \mathrm{dmp}^{2-} \longrightarrow\left[\mathrm{Fe}_{2}(\mathrm{dmp})_{3}\right]^{2-}
\end{aligned}
$$

となって $\mathrm{MeOH}$ 中に溶解した。これらの錯体の $\mathrm{p} K_{\mathrm{st}}$ から見ると $\mathrm{H}_{2} \mathrm{dmp}$ の方がはるかに錯体を作りやすく, アノード反応が錯体生成によって促進されたことを示し た。 $\mathrm{H}_{2}$ cat は $\mathrm{Fe}^{2+}$ と反応し,

$$
\mathrm{Fe}^{2+}+2 \mathrm{Hcat}^{-} \longrightarrow\left[\mathrm{Fe}(\mathrm{Hcat})_{2}\right]
$$

錯体の沈殿皮膜を $\mathrm{Fe}$ 表面に作るために，アノード反応 を抑制した。 $\mathrm{H}_{2} \mathrm{dmp}$ と $\mathrm{H}_{2}$ cat を添加した無水 $\mathrm{MeOH}$ 中における溶液中と $\mathrm{Fe}$ 表面の生成物質は XPS と FTIR 分光法によって詳しく調べられた27)。

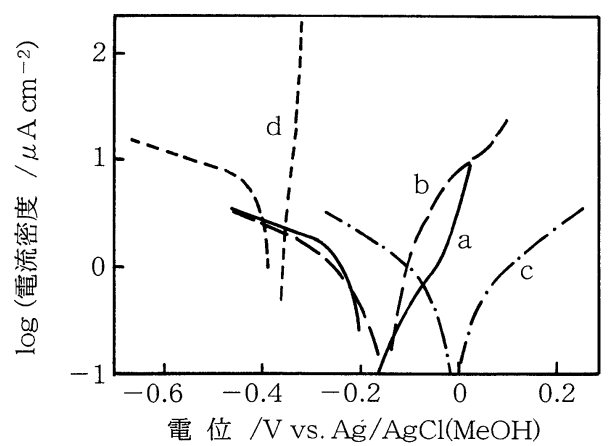

図 $80.1 \mathrm{M} \mathrm{LiClO}_{4}$ と $1 \times 10^{-4} \mathrm{M}$ の錯化剂を含む無 水 $\mathrm{MeOH}$ 中における $\mathrm{Fe}$ 電極の分極曲線 $-2^{26)}$

（a）錯化剂無添加, (b) Hacac, (c) $\mathrm{H}_{2}$ cat, (d) $\mathrm{H}_{2} \mathrm{dmp}$ 添加

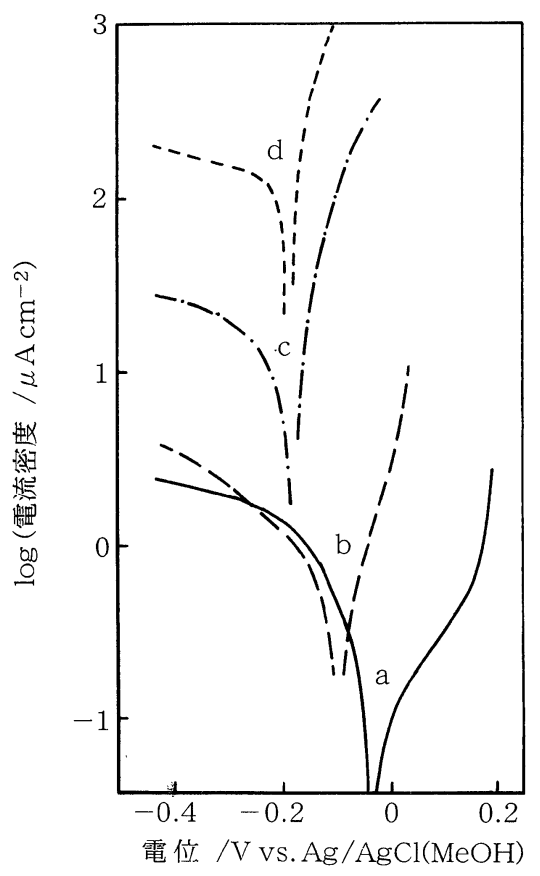

図 $90.1 \mathrm{M} \mathrm{LiClO}_{4}$ と種々の濃度の $\mathrm{FeCl}_{3}$ を含む無 水 $\mathrm{MeOH}$ 中における $\mathrm{Fe}$ 電極の分極曲線 ${ }^{28}$

(a) 無添加, (b) $1 \times 10^{-4} \mathrm{M}$, (c) $1 \times 10^{-3} \mathrm{M}$, (d) $1 \times 10^{-2} \mathrm{M}$ の $\mathrm{FeCl}_{3}$ 添加

6. $\mathrm{FeCl}_{3}$ を含む無水 $\mathrm{MeOH}$ と $\mathrm{AN}$ 中の $\mathrm{Fe}$ 腐食 ${ }^{28), 29)}$ $\mathrm{Fe}^{3+}$ は $\mathrm{H}^{+}$と同じように電子を受容しやすく, 酸化 剂として作用するので, $\mathrm{FeCl}_{3}$ は非水溶媒中で $\mathrm{HCl}$ と 似た溶質として働き，Fe を腐食すると予想される。図 9 に種々の濃度の $\mathrm{FeCl}_{3}$ と $0.1 \mathrm{M} \mathrm{LiClO}_{4}$ を添加した $\mathrm{MeOH}$ 中における $\mathrm{Fe}$ の分極曲線を示す。 $\mathrm{FeCl}_{3}$ 濃度 の増加と共にカソード，アノード両反応とも大きく加速

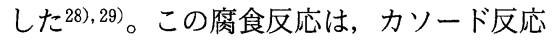

$$
\mathrm{Fe}^{3+}+\mathrm{e}^{-} \longrightarrow \mathrm{Fe}^{2+}
$$


と(14)〜 (17)式 $\left(\mathrm{X}^{-}: \mathrm{Cl}^{-}\right)$の $\mathrm{Cl}^{-}$表面錯体を経るアノー ド反応によって触媒作用的に進行し， $0.01 \mathrm{M} \mathrm{FeCl}_{3}$ を 含む $\mathrm{MeOH}$ 中の腐食電流密度 $i_{\text {cor }}$ は $0.12 \mathrm{mAcm}^{-2}$ で, $0.5 \mathrm{M} \mathrm{HCl}$ 水溶液中の $\mathrm{Fe}$ の $i_{\text {cor }} 0.05 \mathrm{mAcm}^{-2}$ より大 きかった。

電解質無水 $\mathrm{AN}$ に $\mathrm{FeCl}_{3}$ を添加した場合も全く同様 で，(23)式によるカソード反応と（14）（17）式によるア ノード反応によって Fe 腐食は促進された ${ }^{30)}$ 。以上のよ うに，カソード反応を促進する酸化剂と $\mathrm{Cl}^{-}$のように アノード反応を促進する吸着種が存在する場合, 表面に 腐食生成物の沈殿皮膜ができなければ, 電解質無水有機 溶媒中において速い $\mathrm{Fe}$ 腐食が進行する。水溶液中で起 こる $\mathrm{OH}^{-}$の吸着を経る(14)〜 (17)式のアノード反応よ りも速い反応が起こるものと予想される ${ }^{25)}$ 。不働態皮 膜が生成しにくい電解質無水有機溶媒中における金属の 電気化学的腐食は，水溶液中と比べて同等あるいはそれ 以上の激しさで起こる可能性があることを認識すべきで ある。

\section{7. $\mathrm{FeCl}_{3}$ を含む無水 $\mathrm{MeOH}$ と $\mathrm{AN}$ 中の $\mathrm{Fe}$ 腐食の 抑制29), 31), 32)}

$\mathrm{FeCl}_{3}$ を含む電解質無水 $\mathrm{MeOH}$ 中の $\mathrm{Fe}$ 腐食を防ぐ ために，腐食抑制剂を検討した。この腐食系は(23)式の カソード反応と(14) (17)式のアノード反応によって進 行するので, 酸性水溶液中の $\mathrm{Fe}$ 表面と同様に裸の $\mathrm{Fe}$ 表面が露出している。したがって, 酸性水溶液中の $\mathrm{Fe}$ 腐食の抑制に使われる吸着型抑制剤が有効であると思わ れる。ただし，溶液中の $\mathrm{Fe}^{3+}$ と反応するような抑制剤 は用いられない。たとえば， $\mathrm{I}^{-}$は酸性水溶液中の $\mathrm{Fe}$ 腐 食に有効な抑制剂であるが， $\mathrm{Fe}^{3+}$ によって酸化されて $\mathrm{I}_{3}$-となるので効果が低下する。ここではアニオン抑制 剂としての臭化物イオン $\mathrm{Br}^{-}$とカチオン抑制剤として のトリメチルヘキサデシルアンモニウムイオン $\mathrm{C}_{16} \mathrm{H}_{33} \mathrm{~N}$ $\left(\mathrm{CH}_{3}\right)_{3}{ }^{+}$(略号 $\left.\mathrm{TMHA}^{+}\right)$およびそれらの相乗効果に ついて述べ，さらに中性分子の抑制剂であるジメチルへ キサデシルアミン $\mathrm{C}_{16} \mathrm{H}_{33} \mathrm{~N}\left(\mathrm{CH}_{3}\right)_{2}$ (DMHA) とへキ サデカンチオール $\mathrm{C}_{16} \mathrm{H}_{33} \mathrm{SH}$ (HT) の抑制作用について 述べよう。

図10は抑制剂無添加および $1 \times 10^{-2} \mathrm{M} \mathrm{Br}^{-}$, $\mathrm{TMHA}^{+}$および両者を添加した時の $0.01 \mathrm{M} \mathrm{FeCl}_{3}$ を含 む電解質無水 $\mathrm{MeOH}$ 中の $\mathrm{Fe}$ 電極の分極曲線である。 $\mathrm{Br}^{-}$および $\mathrm{TMHA}^{+}$の添加によってカソード，アノー ド両反応共に抑制されたが, 前者がアノード反応を, 後 者がカソード反応をより大きく抑制した。 $\mathrm{Br}^{-}$は正に帯 電した表面に，TMHA+ 着しやすいので，このような結果になったものである。 両者を混合した時はカソード，アノード反応共によく抑

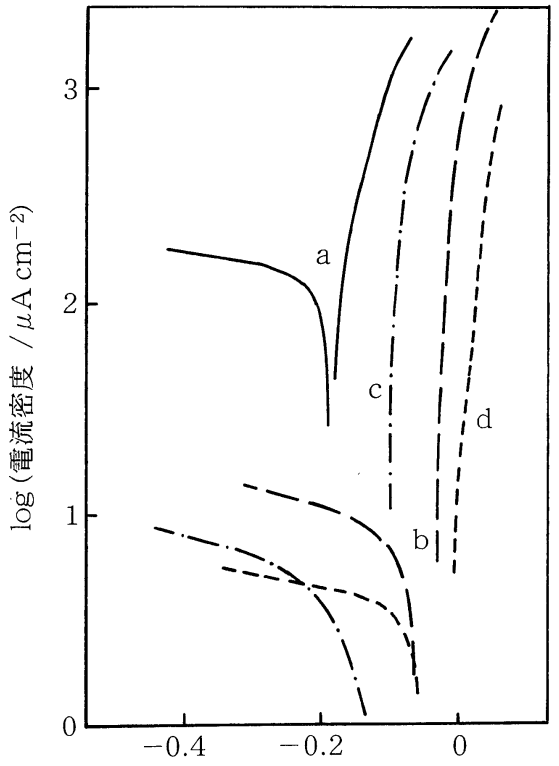

電 位 / V vs. $\mathrm{Ag} / \mathrm{AgCl}(\mathrm{MeOH})$

図10 $0.1 \mathrm{M} \mathrm{LiClO}_{4}$ と0. $01 \mathrm{M} \mathrm{FeCl}_{3}$ を含む無水 $\mathrm{Me}$ $\mathrm{OH}$ 中における $\mathrm{Fe}$ 電極の分極曲線に及ぼすアニ オンおよびカチオン抑制剂添加の影響31)

(a)無添加, (b) $1 \times 10^{-2} \mathrm{M} \mathrm{Br}^{-}$, (c) $1 \times 10^{-2}$ $\mathrm{M} \mathrm{TMHA}^{+}$, (d) $1 \times 10^{-2} \mathrm{M} \mathrm{Br}^{-}+1 \times 10^{-2} \mathrm{M}$ $\mathrm{TMHA}^{+}$添加

制し，相乗的な効果を示した。これらの分極曲線から得 られた腐食電流密度から抑制率 $I$ を求めた。

$$
I(\%)=100\left(1-i_{\text {cor }} / i_{\text {cor }}{ }^{0}\right)
$$

ただし， $i_{\text {cor }}{ }^{0} ， i_{\text {cor }}$ はそれぞれ抑制剤無添加および添加 時の腐食電流密度である。I は $\mathrm{Br}^{-}$が $92.8 \%$, $\mathrm{TMHA}^{+}$が $98.1 \%$ ，そして両者を添加した時が $98.5 \%$ であった。 $\mathrm{FeCl}_{3}$ を含む無水 $\mathrm{MeOH}$ 中の $\mathrm{Fe}$ 腐食に対 するアニオン，カチオン抑制剤の抑制効果之両者の相乗 効果は, 酸性水溶液中の $\mathrm{Fe}$ 腐食に対するもの之同様に 高い効果があった ${ }^{31)}$ 。これらの抑制効果が各イオンの 吸着によることを確認する目的で，インピーダンス測定 によって二重層容量 $C_{\mathrm{d} 1}$ を求めた。図11 に抑制剂無添 加および $1 \times 10^{-2} \mathrm{M} \mathrm{Br}^{-}, \quad \mathrm{TMHA}^{+}$および両者を添加 した時の $0.01 \mathrm{M} \mathrm{FeCl}_{3}$ 無水 $\mathrm{MeOH}$ 中の $\mathrm{Fe}$ 電極の $C_{\mathrm{dl}}$ と電位の関係を示す。これらのイオンの添加によって $C_{\mathrm{d} 1}$ は低下し， $\mathrm{Fe}$ 表面にイオンが吸着していることを 示した ${ }^{33)}$ 。無添加時と比べて $\mathrm{Br}^{-}$添加によって高い電 位で $C_{\mathrm{d} \mathrm{d}}$ は低下するのでよく吸着し， $\mathrm{TMHA}^{+}$の添加 は低い電位で $C_{\mathrm{d} 1}$ が低下してよく吸着した。カチオンが 高い電位でも吸着するのは溶液中の $\mathrm{Cl}^{-}$と共吸着する ためである。両者の添加によって全電位領域でさらに $C_{\mathrm{d} 1}$ は低下し, 強い共吸着が行われることを示した ${ }^{32)}$ 。

図12 は無添加および $1 \times 10^{-2}$ M DMHA を添加した 


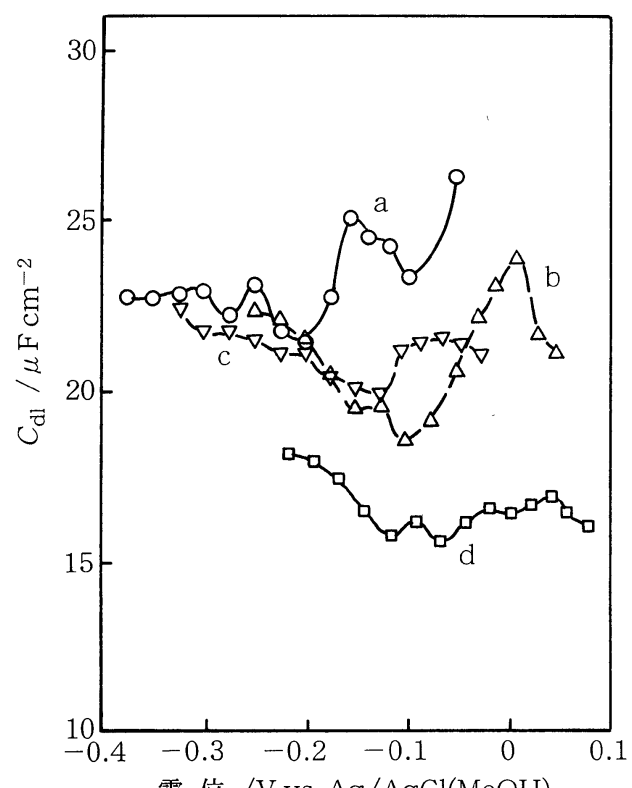

図11 $0.1 \mathrm{M} \mathrm{LiClO}_{4}$ と0.01 $\mathrm{M} \mathrm{FeCl}_{3}$ を含む無水 $\mathrm{Me}$ $\mathrm{OH}$ 中における $\mathrm{Fe}$ 電極の二重層容量 $C_{\mathrm{d} 1}$ に及ぼ すアニオンおよびカチオン抑制剂添加の影響31)

(a) 無添加, (b) $1 \times 10^{-2} \mathrm{M} \mathrm{Br}^{-}$, (c) $1 \times 10^{-2}$ $\mathrm{M} \mathrm{TMHA}^{+}$, (d) $1 \times 10^{-2} \mathrm{M} \mathrm{Br}^{-}+1 \times 10^{-2} \mathrm{M} \mathrm{T}$ $\mathrm{MHA}^{+}$添加

$0.01 \mathrm{M} \mathrm{FeCl}_{3}$ を含む電解質無水 $\mathrm{MeOH}$ 中の $\mathrm{Fe}$ の分極 曲線と $C_{\mathrm{d} 1}$ の電位変化である。この抑制剤の添加によっ て $C_{\mathrm{dl}}$ は低下し, $\mathrm{Fe}$ 表面に化学吸着していることを暗 示した。

$$
\begin{aligned}
\mathrm{Fe}+\mathrm{C}_{16} \mathrm{H}_{33}\left(\mathrm{CH}_{3}\right)_{2} \mathrm{~N}: & \\
& \longrightarrow \mathrm{Fe}: \mathrm{N}\left(\mathrm{CH}_{3}\right)_{2} \mathrm{C}_{16} \mathrm{H}_{33}
\end{aligned}
$$

その結果, $\mathrm{Fe}$ 腐食はカソード, アノード反応共に抑 制され，Iは $98.3 \%$ 之高い值であった ${ }^{32)}$ 。従来, アミ ンの化学吸着が酸性水溶液中の $\mathrm{Fe}$ 表面で起こるという 前提で論議され，吸着挙動や抑制効果が化学吸着によっ て説明されている ${ }^{34)}$ 。しかし, 酸性水溶液中でアミン は

$$
\mathrm{C}_{16} \mathrm{H}_{33} \mathrm{~N}\left(\mathrm{CH}_{3}\right)_{2}+\mathrm{H}^{+} \longrightarrow \mathrm{C}_{16} \mathrm{H}_{33} \mathrm{NH}\left(\mathrm{CH}_{3}\right)_{2}{ }^{+}
$$

となって静電吸着することもあり得るので, 酸性水溶液 中で取り扱っている限り, 化学吸着だけを取り出して論 議することは不可能であった。 $\mathrm{FeCl}_{3}$ を含む無水 $\mathrm{MeOH}$ 中の $\left[\mathrm{H}^{+}\right]$は不純物の水を配慮しても $2.8 \times$ $10^{-8} \mathrm{M}$ 程度であって, 酸性水溶液中の $\left[\mathrm{H}^{+}\right]$之比較し て極端に低くく，(26)式によって生成するカチオンの量 は無視できるので，(25)式の化学吸着が主に起こる。こ うして, 非水溶液中の研究からアミンの化学吸着が実証 された ${ }^{22)}$ 。

中性抑制剂 $\mathrm{HT}$ は $\mathrm{Au}$ や $\mathrm{Cu}$ 表面に強い化学吸着し ${ }^{35)}$,

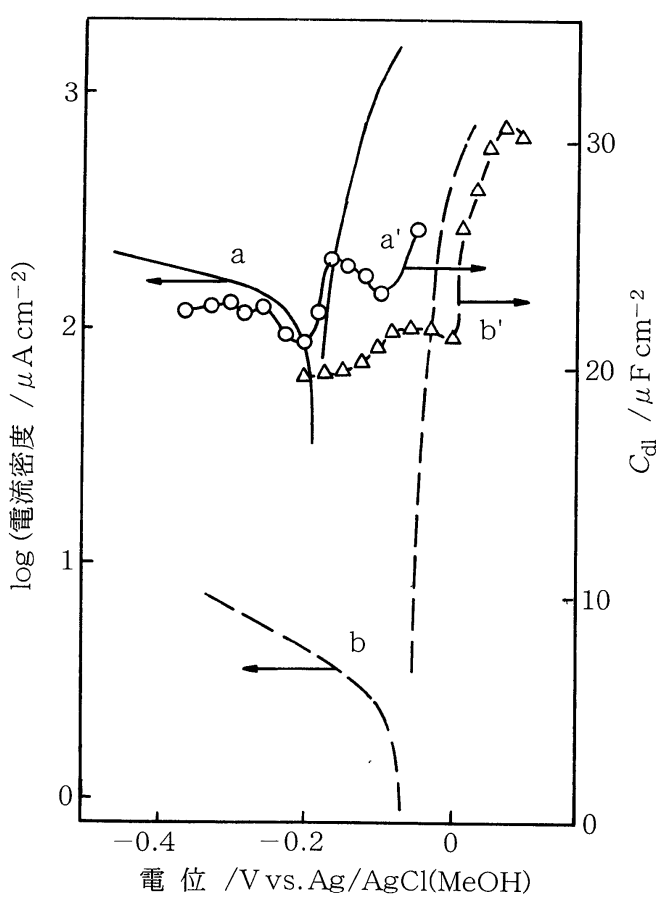

図12 $0.1 \mathrm{M} \mathrm{LiClO}_{4}$ と0.01 $\mathrm{M} \mathrm{FeCl}_{3}$ を含む無水 $\mathrm{Me}$ $\mathrm{OH}$ 中における $\mathrm{Fe}$ 電極の分極曲線（a）之二重 層容量 $C_{\mathrm{dl}}\left(\mathrm{a}^{\prime}\right)$ に及ぼす $1 \times 10^{-2} \mathrm{M}$ DMHA添 加の影響 $\left(b, b^{\prime}\right)^{32)}$

$\mathrm{Fe}$ 表面にも化学吸着する化合物であるが36)，水に難溶 のために抑制剤として用いにくい。図13に $1 \times 10^{-3} \mathrm{M}$ $\mathrm{HT}$ を添加した $0.01 \mathrm{M} \mathrm{FeCl}_{3}$ を含む無水 $\mathrm{MeOH}$ 中の $\mathrm{Fe}$ 電極の分極曲線と $C_{\mathrm{d} 1}$ の電位変化を示す。この抑制 剂は,

$\mathrm{Fe}+\mathrm{C}_{16} \mathrm{H}_{33} \mathrm{SH} \longrightarrow \mathrm{Fe}: \mathrm{SC}_{16} \mathrm{H}_{33}+\mathrm{H}^{+}+\mathrm{e}^{-}$

のように化学吸着する。HT の添加により $C_{\mathrm{d} 11}$ は低下 し, 化学吸着したことを示した。分極曲線はカソード,

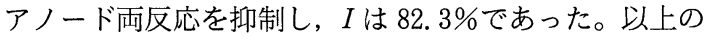
ように, $\mathrm{FeCl}_{3}$ を含む電解質無水 $\mathrm{MeOH}$ 中の $\mathrm{Fe}$ の腐 食は吸着型抑制剤によって抑制できた。また, $\mathrm{FeCl}_{3}$ を含む $\mathrm{AN}$ 中でも $\mathrm{Fe}$ の腐食を吸着型抑制剤によって同 様に抑制できることが明らかになった ${ }^{30)}$ 。

\section{8. おわりに}

筆者の研究室で行った含水量の低い有機溶媒中の $\mathrm{Fe}$ の腐食と抑制について述べた。これらの研究を通じて, 無水であっても電解質溶液中では水溶液と類似の腐食反 応が起こり，その抑制も同様に行えることが明らかに なった。無水有機溶媒中と水溶液中とで大きな相違は水 による不㗢態化が起こらない点で, $\mathrm{Al}, \mathrm{Ti}$, ステンレス 鋼のような不働態皮膜によって腐食を防止している金属 では，無水有機溶媒中で不㗢態皮膜が破壊されると激し 


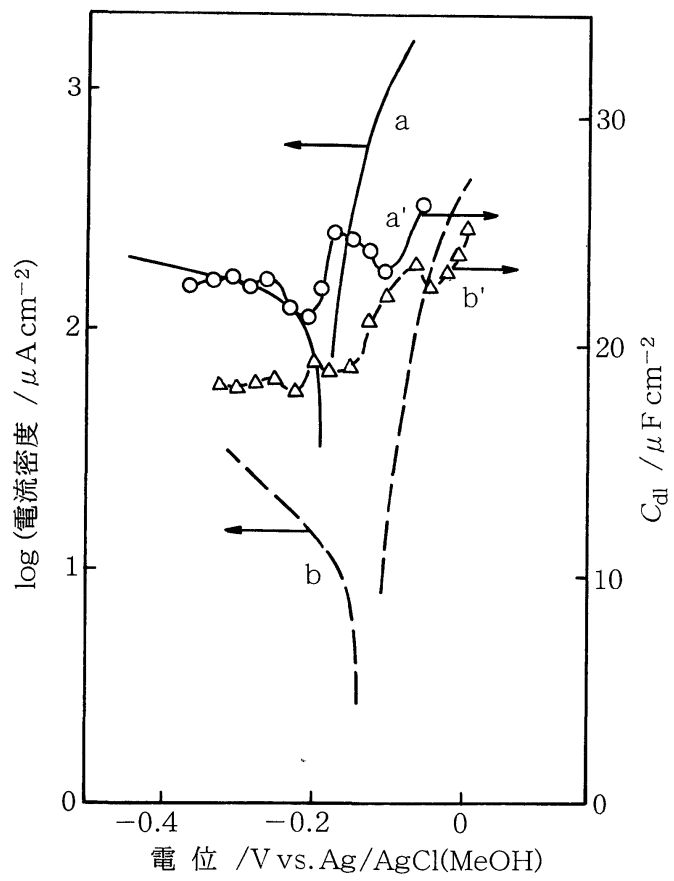

図13 0.1 $\mathrm{M} \mathrm{LiClO}_{4}$ と $0.01 \mathrm{M} \mathrm{FeCl}_{3}$ を含む無水 $\mathrm{Me}$ $\mathrm{OH}$ 中における $\mathrm{Fe}$ 電極の分極曲線（a）之二重 層容量 $C_{\mathrm{dl}}\left(\mathrm{a}^{\prime}\right)$ に及ぼす $1 \times 10^{-3} \mathrm{M} \mathrm{HT}$ 添加の 影響 $\left(b, b^{\prime}\right)^{32)}$

い活性溶解を起こす可能性がある。したがって，水の混 入が腐食挙動に大きく影響することになる。

(1998 年 11 月 25 日受理)

\section{文献}

1) E. Heitz: Corrosion of Metals in Organic Solvents, "Advances in Corrosion Science and Technology", ed. by M. G. Fontana and R. W. Staehle, Vol. 4, p.149, Prenum Press, New York (1974).

2 ）荒牧国次：環境の腐食作用，非水溶液，「防食技 術便覧」, 腐食防食協会編, p.291, 日刊工業新聞 社, (1986).

3 ）荒牧國次 : 防錆管理, 42, 130 (1998).

4 ）関根 功: 表面, 27, 160 (1989).

5 ）関根 功, 湯浅 真, 可児一郎 : 材料と環境, 46, 424 (1997).

6 ) J. T. Demo, Jr.: Chem. Eng. World, 7, 115 (1972).

7 ) P. Hronsky: Corrosion, 37, 161 (1981).

8 ) M. H. Koepp, H. Wendt and H. Strehlow: $Z$. Elektrochem., 64, 483 (1960).

9 ）日本化学会編 : 「化学便覧」, 基礎編, 改定 3 版,
II -477, 丸善（1984）。

10）文献 1） p.169.

11) R. G. Kelly and P. J. Moran: Corros. Sci., 30, 495 (1990).

12）山崎博史, 若槻康雄:「有機金属の化学」, 新化学 ライブラリー, 日本化学会編, p. 54, 大日本図書 (1989).

13) M. Stern and H. Uhlig: J. Electrochem. Soc., 99, 381, 389 (1952).

14）藤井晴一, 菅野良士 : 防食技術, 20, 127 (1971).

15) S. W. Vorster: Corros. Sci., 9, 801 (1969).

16) M. Sakakibara, N. Saito, H. Nishihara and K. Aramaki: Corros. Sci., 34, 391 (1993).

17) K. Aramaki, M. Mizoguchi and H. Nishihara: J. Electrochem. Soc., 138, 394 (1991).

18) P. L. De Anna: Corros. Sci., 25, 43 (1985).

19) K. Aramaki, M. Sakakibara and H. Nishihara: Proc. 12th Internat. Corrosion Congr., Vol. 5B, p.3868, NACE, Houston (1993).

20) K. Aramaki, M. Sakakibara, N. Saito and H. Nishihara: 材料之環境, 43， 272 (1994).

21) V I. Vigdorovic, L. E. Tsygankova and T. V. Abramova: Sov. Electrochem., 9, 1087 (1973).

22）日本化学会編 :「化学便覧」, 基礎編, 改定 3 版, II -343, 丸善 (1984).

23) K. Aramaki, K. Shimizu, M. Sakakibara and H. Nishihara: J. Electrochem. Soc., 140, 1561 (1993).

24) Y. Matsumoto, T. Kawai, H. Nishihara and K. Aramaki: Corros. Sci., 38, 1899 (1996).

25) K.Aramaki, M.Hagiwara and H.Nishihara: J. Electrochem. Soc., 135, 1364 (1988).

26) M.Sakakibra, H.Nishihara and K.Aramaki: Corros. Sci., 34, 1937 (1993).

27) T. Kawai, H. Nishihara and K. Aramaki: Corros. Sci., 36, 2111 (1994).

28) T. Kawai, H. Nishihara and K. Aramaki: Corros. Sci., 37, 823 (1995).

29) K. Aramaki, T. Kawai and H. Nishihara: Proc. 8th Eur. Symp. Corrosion Inhibitors, Vol. 2, p. 763, Univ. of Ferrara, Ferrara (1996).

30） K. Aramaki and T. Kikuchi: 未公表.

31) T. Kawai, H. Nishihara and K. Aramaki: Corros. Sci., 38, 225 (1996).

32) T. Kawai, H. Nishihara and K. Aramaki: $J$. Electrochem. Soc., 143, 3866 (1996).

33) K.Aramaki, M.Hagiwara and H.Nishihara: Corros. Sci., 27, 487 (1987).

34) K. Aramaki: 電気化学, 41, 875 (1973).

35) Y.Yamamoto, H.Nishihara and K.Aramaki: J. Electrochem. Soc., 140, 436 (1993).

36) K. Nozawa, H. Nishihara and K. Aramaki: Corros. Sci., 39, 1623 (1997). 